\title{
Analysis of Acute Viral Hepatitis (A and E) in Iraq
}

\author{
Ataallah M. Turky \\ Minstry of Health, Iraq \\ Wijdan Akram \\ Al- kindy College of Medicine, University of Baghdad, Iraq \\ E-mail: najem20042003@yahoo.com
}

Ahmed S. Al-Naaimi

Department of Community Medicine, College of Medicine, University of Baghdad, Iraq

\author{
Ali Rijab Omer \\ Minstry of Health, Iraq \\ Jamal Rasheed Al- Rawi
}

Al- Mustanseryah College of Medicine, Iraq

Received: August 23, 2010 Accepted: September 10, 2010 doi:10.5539/gjhs.v3n1p70

\begin{abstract}
Hepatitis, an inflammation of the liver, has a number of infectious and non-infectious causes. Two of the viruses that cause hepatitis (hepatitis A and E) can be transmitted through water and food; hygiene is therefore important in their control. First, to assess the importance of HAV and HEV as a possible diagnosis for clinically diagnosed patients with acute viral hepatitis. Second, to assess the prevalence of hepatitis A and E in all provinces of Iraq and study its association with age, gender. This study consisted of two groups: The first group consisted of 2975 patients with a clinical diagnosis of acute viral hepatitis. The second group consisted of a total of 9610 persons, which were recruited by surveying a nationally representative random sample of households. A stratified random sample proportional to size of each of the 18 Iraqi governorates, both urban and rural areas was employed. Blood samples were taken from study subjects. The relative frequency of positive anti-HAV IgM antibodies was $41.0 \%$, while anti- HEV IgM represented $19.4 \%$ of patients with a clinical suspicion of acute viral hepatitis. The prevalence of hepatitis A-IgG antibodies in Iraqi population is $96.4 \%$ ( $95 \%$ confidence interval is $96-96.8 \%$ ), while that of Hepatitis E-IgG antibodies was $20.3 \%$ (95\% confidence interval is 19.4-21.2\%). The sero-prevalence showed a steady and significant increase with age for hepatitis E, while it showed an obvious increase between the first and second decade of life for HAV. No significant sex variation was observed for HAV, while males had a higher risk (by 15\%) for HEV. The after war situation in Iraq is disastrous, due to the damage to water supply infrastructure and its contamination with sewage, Hepatitis A is hyper endemic in Iraq, while hepatitis $\mathrm{E}$ is endemic. Among patients with a clinical diagnosis of acute viral hepatitis, two fifths had serologic evidence of type A and another one fifth had type E viral hepatitis.
\end{abstract}

Keywords: HAV, HEV, Iraq, Epidemiology, National survey

\section{Introduction}

Among the infectious causes, hepatitis A and hepatitis E are associated with inadequate water supplies and poor sanitation and hygiene, leading to infection and inflammation of the liver [World Health Organization, 1975]. Hepatitis A and E viruses, while unrelated to one another, are both transmitted via the fecal-oral route, most often through contaminated water and from person to person. Hepatitis continues to be a major health problem in developing and tropical countries [Dienstag JL, 1978]. This is particularly true for hepatitis A virus (HAV) 
where infection occurs during early life leading to nearly $100 \%$ prevalence of antibody to HAV (anti-HAV) in individuals above 10 years of age [Lemon SM., 1985], [Gust I., 1993], [Deodhare SG., 2002]. This infection is present worldwide and is inversely proportional to the levels of environmental sanitation and personal hygiene. In developing countries like India where sanitation and hygiene are unsatisfactory, specially among those belonging to lower socioeconomic group, nearly $100 \%$ of the population is infected as shown by presence of antibodies in early life and manifest infection in adults is rare. In developed countries like the USA only about $40 \%$ of population have antibodies and are thus susceptible to HAV infection [Banker DD, 1999], [Ryan KJ, 2004]. In areas highly endemic for hepatitis A, most infections occur during early childhood. The majority of cases may not show any symptoms; fatal cases due to fulminant acute hepatitis are rare. Nearly all patients recover completely with no long-term effects.

Hepatitis A virus (HAV) has emerged as an important public health problem in many countries of the Middle East region and Iraq is no exception. Hepatitis A (formerly known as infectious hepatitis) is an acute infectious disease of the liver caused by the hepatitis A virus (HAV) [Thiel TK, 1998]. Every year, approximately 10 million people worldwide are infected with the virus. [Kamel MA, 1995]

Despite the availability of highly effective vaccines and recommendations that have been in place for several years, there were more than 13,000 cases of hepatitis A reported in year 2000, making this disease among the most frequently reported vaccine-preventable diseases in the United States [Ramia S., 1986]

HEV infection can occur in large epidemics in endemic regions. Areas with endemic infections and high incidence are in Asia, Africa, Central America and the Middle East. Here the predominant mode of infection is fecal-oral via contaminated water [Belabbes EH, 1985] Until 1997, hepatitis E was thought to occur only in developing countries but there are many sporadic reports from developed nations [Okuda K, 2001], [Tandon BN, 2001]. Vertical transmission of HEV infection from mother to child has been identified. In one study of eight pregnant women with acute hepatitis E, five blood specimens collected from their babies at birth tested positive for HEV RNA. [Khuroo MS, 1995]

The incidence of hepatitis $\mathrm{E}$ is highest in juveniles and adults between the ages of 15 and 40. Though children often contract this infection as well, they less frequently become symptomatic. Mortality rates are generally low, for Hepatitis E is a "self-limiting" disease. Hepatitis E occasionally develops into an acute severe liver disease, and is fatal in about $2 \%$ of all cases. Clinically, is, comparable to hepatitis A, but in pregnant women the disease is more often severe and is associated with a clinical syndrome called fulminant hepatic failure. Pregnant women, especially those in the third trimester, suffer an elevated mortality rate from the disease of around $20 \%$ [Balayan MS 1997; Krawczynski K, 2001].

In 2004, there were two major outbreaks of Hepatitis E, both of them in sub-Saharan Africa. There was an outbreak in Chad in which, as of September 27, were 1,442 reported cases and 46 deaths. The second was in Sudan with, as of September 28, 6,861 cases and 87 deaths. Increasingly, hepatitis E is being seen in developed nations with reports of cases in the UK, US and Japan. The disease is thought to be a zoonosis [Feagins AR, 2007]. There are controversies about parenteral transmission of HEV infection. Some studies revealed that unlike other enterically transmitted infections, person-to-person transmission of HEV occurs infrequently [Aggarwal R, 1994]. In hemodialysis patients the HEV infection may be transmitted from person to person in the hemodialysis unit as a nosocomial infection [Ayoola EA, 2002].

Iraq is a country with few suspected outbreaks of HEV. Starting in May 2004, an outbreak of acute hepatitis was identified in several cities of Baghdad including Al-Sader, AL-Ubidy and AL-Kamalya, in Al- Rusafa district, Al-Mahmodya and Abu Graib Cities, in Al -Karkh district [Minstry of health, 2004, 2005, 2006]. Hepatitis is now also reported from Basrah governorate, south of Iraq. The disease was recognized among young adults, pregnant women with few deaths among them and was therefore clinically diagnosed as HEV. Hepatitis E is prevalent in most developing countries, and common in any country with a hot climate [Uchida T., 1992].

In this paper, assess the importance of HAV and HEV as a possible diagnosis for clinically diagnosed patients with acute viral hepatitis. Calculate a national estimate for point prevalence of IgG antibodies of HAV and HEV. In addition, study the association of age, gender and governorate with serum positivity of HAV and HEV.

\section{Subjects and Methods}

The data supported by Ministry of health, Iraq for the period 2005-2006. The study consisted of two groups: The first group consisted of 2975 patients with a clinical diagnosis of acute viral hepatitis. The directorate of health in each Iraqi governorate participated in recruiting study subjects during the one year study period. All patients 
with a clinical diagnosis of acute viral hepatitis and visiting a health care provider in the governmental sector were eligible for inclusion in this group.

The second group consisted of a total of 9610 persons, which were recruited by surveying a nationally representative random sample of households. All apparently healthy family members of the household were eligible for inclusion in the study. The sample of households was provided by the Ministry of planning using a stratified random sample proportional to size of each of the eighteen Iraqi governorates, both urban and rural areas. The proposed total national sample size was 12,000 , which was expected to yield a sample estimate for proportion at its most extreme magnitude of 0.5 , with a $95 \%$ confidence interval of $+/-2 \%$ of the estimate employing the highest power of study possible of $99 \%$. At the governorate level considering an average sample size of 650 per governorate, one would expect to yield a sample estimate for proportion at its most extreme magnitude of 0.5 , with a $95 \%$ confidence interval of $+/-8 \%$ of the estimate employing the highest power of study possible of $99 \%$. The $20 \%$ non-response rate, being non-differential and affected only by poor level of security or logistic problems is not expected to affect the validity of the estimates to any important extent.

Blood samples were taken from study subjects. Three to five $\mathrm{ml}$ of blood was collected from the patients. Serum IgM antibodies and IgG antibodies to HEV, HAV were detected employing a commercially available ELISA. Identifying information including age, sex and residence were also secured.

\section{Statistical analysis}

Statistical analysis was computer aided using SPSS version13 and EPI-Info version 3.5.1 (create map module). The $95 \%$ confidence interval of a proportion was used to calculate the population parameters. The prevalence ratio was used to calculate the magnitude of risk in a group compared to a reference category in a cross-sectional design. The formula used in its calculation and its $95 \%$ confidence interval (natural logarithm based method) are similar to that of risk ratio used in a cohort design [Kleinbaum DG, 2007]. P value less than the 0.05 level of significance was considered statistically significant.

\section{Results}

As shown in table 1, among 2975 patients with a clinical suspicion of acute viral hepatitis, about two fifths (41\%) had positive serum anti-HAV antibodies and another one fifth (19.4\%) had positive HEV IgM antibodies.

In the national population sample $96.4 \%$ were positive for IgG anti-HAV antibodies, while only $20.3 \%$ were positive for anti-HEV IgG antibodies, table 2.

As shown in table 3, the prevalence of HAV IgG antibodies was lowest in the first decade of life (91.3\%), which increased to $96.8 \%$ in the second decade of life. Later on in life no obvious changes in prevalence rate was observed. The risk of testing positive for IgG anti-HAV is increased significantly by around 6 to $7 \%(\mathrm{PR}=1.06$ to 1.07) in older ages compared to children in the first decade of age. No significant gender differences were observed.

As shown in table 4, the prevalence of HEV IgG antibodies was lowest in the first decade of life (13.6\%) and highest in the oldest age group (26.6\% in the $41+$ age group). The risk of testing positive for IgG anti-HEV increases steadily and significantly with age. The risk in the $2^{\text {nd }}$ decade of life is increased by $36 \%$ compared to children in the first decade of life $(\mathrm{PR}=1.36)$, while it is increased by $96 \%(\mathrm{PR}=1.96)$ in the oldest age group ( $41+$ years) compared to children in the first decade of life. The risk in males is significantly higher by $15 \%$ $(\mathrm{PR}=1.15)$ compared to females.

The prevalence rate of positive IgG HAV antibodies was lowest in Dahuk, At Ta'mim, Diyala and Al Basrah (85.2-95\%), figure 1.

The prevalence rate of positive IgG HEV antibodies was highest in Baghdad, A.Najaf, Al-Muthanaband Dahuk governorates (being $>24.6 \%$ ) and lowest in Ninawa, At-Ta'mim, Salah ad Din and Diyala (8.5-17.6\%), figure 2 .

\section{Discussion}

The present work is the largest and most updated population-based sero-epidemiological study of HAV and HEV infection in Iraq. HAV infection is hyper endemic in Iraq with a national estimate of IgG sero-prevalence rate of $98 \%$ in the $5^{\text {th }}$ decade and older age group $(41+)$. The prevalence rate is almost constant from the second decade of life through after, which reflects the bad hygienic situation of the country. The situation in nearby countries like Saudi Arabia is much different. There was a reduction noted in all age groups investigated for anti HAV IgG. This finding points to a decline in the feco-oral transmission of HAV among Saudi children and reflects the marked improvement of hygienic conditions that took place in the Kingdom during the past decades [Saudi Journal of Saudi Arabia. 1995]. 
In the present work, no gender differences were observed for HAV, while males had a slightly higher risk for being positive for HEV. There is no indication of different incidence of acute viral hepatitis A and $\mathrm{E}$ infection among male and female [Frosner G, 1984].

In the present study two fifths of patients with a clinical suspicion of acute viral hepatitis, had positive serologic evidence of HAV infection and another one fifth had positive evidence of HEV infection. Similar findings were reported in Saudi Arabia, patients with acute hepatitis seen in King Khalid University Hospital, Riyadh. Between July 1993-May 1994. The prevalence of HAV among Saudi patients with acute icteric hepatitis, was $38.3 \%$. It is possible that HEV was the etiological agent for some of hepatitis cases [Saudi Journal of Saudi Arabia. 1995].

HEV infection is endemic in Iraq, acquired early in life and its seroprevalence rate increased steadily with age, reaching $26.6 \%$ in age group $41+$. HEV is an important cause of Non-A Non-B viral hepatitis. Epidemics and point source out-breaks are common in rainy season when flooding leads to sewage contamination of drinking water [Chin KP, 1991]. Occurrence of HEV specific IgM was noted in $19.4 \%$ of serum samples from patients with a clinical suspicion of hepatitis. Our data fits with the existing epidemiological features of HEV in endemic areas. HEV specific IgM was noted in $18.8 \%$ of tested serum samples of a hospital based study of Hepatitis E by serology in India [ Indian J Med Microbiol 2003]. In the national general population sample hepatitis E infection represented $20.3 \%$ of the total Iraqi sample. This means that the disease is endemic in Iraq. A steady increase in prevalence is observed with advancing age. Studies from Yemen [Gunaid A., 1997] and India [Khuroo M.S, 1996] revealed the etiological role of HEV in $28 \%$ and $38 \%$ of cases with acute sporadic NANBH. The patterns of increase are similar to those reported in many other studies from different endemic countries [Arankalle VA, 1995; Alvarez-Munoz MT, 1999]. In north India, a region with high endemicity for HEV infection, exposure to HEV was shown to occur in early life and seropositivity for anti-HEV IgG increased progressively from $7.2 \%-14.2 \%$ in infancy to $33.3 \%-38.0 \%$ by 10 years of age in rural and urban children respectively [Mathur $\mathrm{P}$, 2001]. A similar epidemiological picture was also seen in other studies from Turkey [Thomas DL 1993; Sidal M, 2001], Saudi Arabia [Arif M, 1994] and Egypt.

\section{Conclusions}

Among patients with a clinical diagnosis of acute viral hepatitis, only two fifths had serologic evidence of type A and another one fifth type E viral hepatitis. Hepatitis A is hyper-endemic in Iraq, with no gender differences. Serologic evidence of previous exposure to the infective agent is present in the majority of general population (96.4\%). It is a disease of childhood. After the second decade of life no obvious increase in its prevalence is noticed. Hepatitis $\mathrm{E}$ is endemic in Iraq with a prevalence of its serologic marker (IgG antibody) of 20.3\%. Males have a slightly higher prevalence rate. A steady increase in prevalence is observed with advancing age.

\section{Recommendations}

Health education about mode of transmission, complications and preventive measures against viral hepatitis A and $\mathrm{E}$, like personal hygiene, especially hand-washing. Raising the issue of the cost of human suffering in addition to economic losses because of acute viral hepatitis in health promotion messages needs to be evaluated for effectiveness by another national study. Primary prevention of HAV, HEV infection is the cornerstone of control in Iraq and solely depends on environmental sanitation.

\section{References}

A hospital based study of Hepatitis E by serology. Indian J Med Microbiol, (2003). 21:115-7.

Aggarwal R, Naik SR. (1994). Hepatitis E: intrafamilial transmission versus waterborne spread. $J$ Hepatol. 21(5):718-23.

Alvarez-Munoz MT et al. (1999). Seroepidemiology of hepatitis E virus infection in Mexican subjects 1-29 years of age - preliminary report. Archives of medical research, 30:251-4.

Arankalle VA et al. (1995). Age-specific prevalence of antibodies to hepatitis A and E viruses in Pune, India, 1982 and 1992. Journal of infectious diseases, 117:447-50.

Arif M et al. (1994). Epidemiology of hepatitis E virus (HEV) infection in Saudi Arabia. Annals of tropical medicine and parasitology, 88(2):163-8.

Ayoola EA, Want MA, Gadour MO, Al-Hazmi MH, Hamza MK. (2002). Hepatitis E virus infection in haemodialysis patients: a case-control study in Saudi Arabia. J Med Virol. 66(3):329-34.

Balayan MS. (1997). Epidemiology of hepatitis E virus infection. J Viral Hepat, 4(3):155-65. 
Banker DD. (1999). Modem Practice in Immunization. 4th edn. Mumbai: Universal Publishing Corporation, pp. 423.

Belabbes EH, Bouguermouh A, Benatallah A, Illoul G. (1985). Epidemic non-A, non-B viral hepatitis in Algeria: strong evidence for its spreading by water. J Med Virol, 16: 257-63.

Chin KP, Lok AS, Wong LS, Lai CL, WU PC. (1991). Current seroepidemiology of hepatitis A in Hong Kong. $J$ Med Virol, 34:191-3.

Deodhare SG. (2002). General Pathology and Pathology of Systems. 6th edn. Mumbai: Popular Prakashan, pp. 1111-30.

Dienstag JL, Szmuness W, Stevens CE, Purcell RH. (1978). Hepatitis A virus infection. New insights from seroepidemiologic studies. $J$ Infect Dis, 137:328-40.

Feagins AR, Opriessnig T, Guenette DK, Halbur PG, Meng XJ. (2007). Detection and characterization of infectious Hepatitis E virus from commercial pig livers sold in local grocery stores in the USA. $J$ Gen Virol.; 88(Pt 3):912-7.

Frosner G. (1984). Hepatitis A virus: text book of human virology. Belch R Bed PGS. Publishing company Littleton, Mass ehuest. Chapter 24,707-727.

Gunaid A., Nasher T., EL- Gunaid E.et al. (1997). Acute sporadic hepatitis in Yemen. J.Med Viral., 51 (1): 64-66,.

Gust I. (1993). Epidemiological patterns of hepatitis A in different parts of the world. Vaccine, 10(Suppl.I):S56-S58.

Kamel MA et al. (1995). Seroepidemiology of hepatitis E virus in the Egyptian Nile Delta. Journal of medical virology, 47:399-403.

Khuroo M.S. (1996). HepatitisE virus: another addition to the existing alphabet of human hepatitis viruses. Annals of Saudi Medicine, 16(3), 308-318.

Khuroo MS, Kamili S, Jameel S. (1995). Vertical transmission of hepatitis E virus. Lancet, 345: 1025-6.

Kleinbaum DG, Sullivan KM, Barker ND. (2007). A pocket guide to Epidemiology. First ed, New York, USA, Springer Science and Business media: 71-91.

Krawczynski K, Kamili S, Aggarwal R. (2001). Global epidemiology and medical aspects of hepatitis E. Forum (Genova). 11(2):166-79.

Lemon SM. (1985). Type A viral hepatitis: new developments in an old disease. N Engl J Med, 313:1059-67.

Mathur P et al. (2001). Sero-epidemiology of hepatitis E virus (HEV) in urban and rural children of North India. Indian pediatrics, 38:461-74.

Minstry of health / Iraq/ CDC Baghdad, Viral Hepatitis Section 2004, 2005, 2006.

Okuda K, Hai Y. (2001). Acute hepatitis and acute hepatic failure. In: Hepatobiliary diseases: Pathophysiology and Imaging, Ist ed. Okuda K, Mitchell DG, Itai Y, Ariyama J. Eds., (Blackwell Science, U.K):88-89.

Ramia S. (1986). Antibody against hepatitis A in Saudi Arabians and in expatriates from various parts of the world working in Saudi Arabia. J Infest, 12:153-5.

Reduction in the prevalence of antibody to hepatitis A virus among young Saudi adults: Implications for hepatitis A vaccine. Saudi Journal of Saudi Arabia. (1995). volume: 1, Issue: 2, page: 93-96.

Ryan KJ, Ray CG. (2004). Sherris Medical Microbiology (4th ed.). McGraw Hill. pp. 541-4.

Sidal M et al. (2001). Age-specific seroepidemiology of hepatitis A, B, and E infections among children in Istanbul, Turkey. European journal of epidemiology, 17(2):141-4.

Tandon BN. (2001). Viral hepatitis in tropics and its management, JAMA India - The physicians' Update; 4:102-106.

Thiel TK. (1998). "Hepatitis A vaccination". Am Fam Physician 57 (7): 1500, PMID 9556642.

Thomas DL et al. (1993). Epidemiology of hepatitis E virus infection in Turkey. Lancet, 341:1561-2.

Uchida T. (1992). Hepatitis E: review. Gastroenterol Jpn. 27(5):687-96.

World Health Organization Viral Hepatitis. Technical Report Series No. 570. Report of a WHO meeting, Geneva. (1975). 
Table 1. The relative frequency of positive anti-HAV and anti-HEV IgM antibodies among subjects with a clinical diagnosis of acute hepatitis

\begin{tabular}{lcccc}
\hline & Total examined & \multicolumn{2}{c}{ Positive } & \\
Overall & $\mathrm{N}$ & $\mathrm{N}$ & $\%$ & $95 \%$ CI for prevalence rate (\%) \\
\hline Anti - HAV IgM & 2975 & 1219 & 41.0 & $(39.2-42.8)$ \\
Anti - HEV IgM & 2975 & 577 & 19.4 & $(18-20.8)$ \\
\hline
\end{tabular}

Table 2. The prevalence rate of anti-HAV and HEV IgG antibodies in a nationally representative Iraqi general population sample

Total examined Positive serum $\mathrm{Ab}$

\begin{tabular}{lcccc} 
& $\mathrm{N}$ & $\mathrm{N}$ & $\%$ & $95 \%$ CI for prevalence rate (\%) \\
\hline Positive Anti-HAV IgG & 9610 & 9268 & 96.4 & $(96-96.8)$ \\
Positive Anti-HEV IgG & 6972 & 1415 & 20.3 & $(19.4-21.2)$
\end{tabular}

Note: $27.5 \%$ of the total sample were not analyzed for HEV IgG antibodies, because of technical difficulties.

Table 3. The prevalence rate of positive serum anti-HAV IgG antibodies by age and gender in a nationally representative sample

\begin{tabular}{lccccccc}
\hline \multicolumn{7}{c}{$\begin{array}{c}\text { Total } \\
\text { examined } \\
\end{array}$} & \multicolumn{2}{c}{$\begin{array}{c}\text { Positive Anti-HAV } \\
\text { IgG }\end{array}$} & $\mathrm{N}$ & $\%$ & $\begin{array}{c}\text { 95\% CI for } \\
\text { prevalence rate }(\%)\end{array}$ & $\begin{array}{c}\text { Prevalence } \\
\text { ratio(PR) }\end{array}$ & $95 \%$ CI for PR & P \\
\hline Age group & & & & & & & \\
$(1-10)$ & 1641 & 1498 & 91.3 & $(89.9-92.7)$ & Ref & & \\
$(11-20)$ & 2235 & 2164 & 96.8 & $(96.1-97.5)$ & 1.06 & $(1.04-1.08)$ & $<0.001$ \\
$(21-30)$ & 2374 & 2323 & 97.9 & $(97.3-98.5)$ & 1.07 & $(1.05-1.09)$ & $<0.001$ \\
$(31-40)$ & 1603 & 1562 & 97.4 & $(96.6-98.2)$ & 1.07 & $(1.05-1.09)$ & $<0.001$ \\
$41+$ & 1757 & 1721 & 98 & $(97.3-98.7)$ & 1.07 & $(1.06-1.09)$ & $<0.001$ \\
Gender & & & & & & & \\
Female & 4856 & 4676 & 96.3 & $(96.1-97.1)$ & Ref & & \\
Male & 4754 & 4592 & 96.6 & $(95.8-96.8)$ & 1.00 & $(1-1.01)$ & $0.43[\mathrm{NS}]$ \\
\hline
\end{tabular}

Table 4. The point prevalence rate of positive serum anti-HEV IgG antibodies by age and gender in a nationally representative sample

\begin{tabular}{|c|c|c|c|c|c|c|c|}
\hline & \multirow{2}{*}{$\begin{array}{c}\text { Total } \\
\text { examined } \\
\mathrm{N}\end{array}$} & \multicolumn{2}{|c|}{$\begin{array}{c}\text { Positive Anti-HEV } \\
\text { IgG }\end{array}$} & \multirow{2}{*}{$\begin{array}{c}95 \% \mathrm{CI} \text { for } \\
\text { prevalence rate }(\%)\end{array}$} & \multirow{2}{*}{$\begin{array}{c}\text { Prevalence } \\
\text { ratio(PR) }\end{array}$} & \multirow[b]{2}{*}{$95 \% \mathrm{CI}$ for $\mathrm{PR}$} & \multirow[b]{2}{*}{$\mathrm{P}$} \\
\hline & & $\mathrm{N}$ & $\%$ & & & & \\
\hline \multicolumn{8}{|c|}{ Age group } \\
\hline$(1-10)$ & 1051 & 143 & 13.6 & $(11.5-15.7)$ & Ref & & \\
\hline$(11-20)$ & 1648 & 305 & 18.5 & $(16.6-20.4)$ & 1.36 & $(1.13-1.63)$ & $<0.001$ \\
\hline$(21-30)$ & 1737 & 358 & 20.6 & $(18.7-22.5)$ & 1.51 & $(1.27-1.81)$ & $<0.001$ \\
\hline$(31-40)$ & 1244 & 265 & 21.3 & $(19-23.6)$ & 1.57 & $(1.3-1.89)$ & $<0.001$ \\
\hline $41+$ & 1292 & 344 & 26.6 & $(24.2-29)$ & 1.96 & $(1.64-2.34)$ & $<0.001$ \\
\hline \multicolumn{8}{|l|}{ Gender } \\
\hline Female & 3573 & 677 & 18.9 & $(20.3-23.1)$ & Ref & & \\
\hline Male & 3399 & 738 & 21.7 & $(17.6-20.2)$ & 1.15 & $(1.04-1.26)$ & 0.004 \\
\hline
\end{tabular}




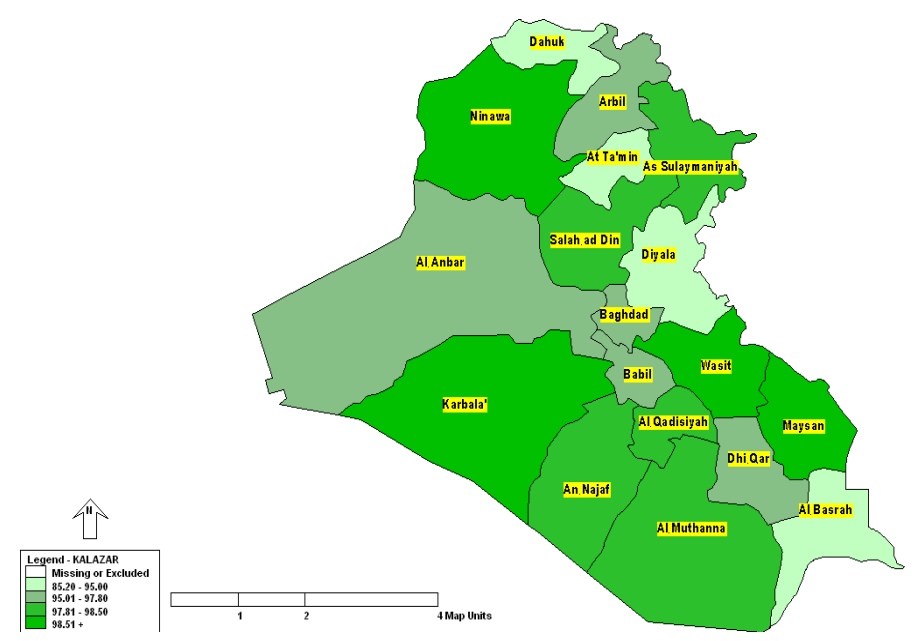

Figure 1. The point prevalence rate of positive serum anti-HAV IgG antibodies in 18 Iraqi governorates in a nationally representative general population sample of 9610 person

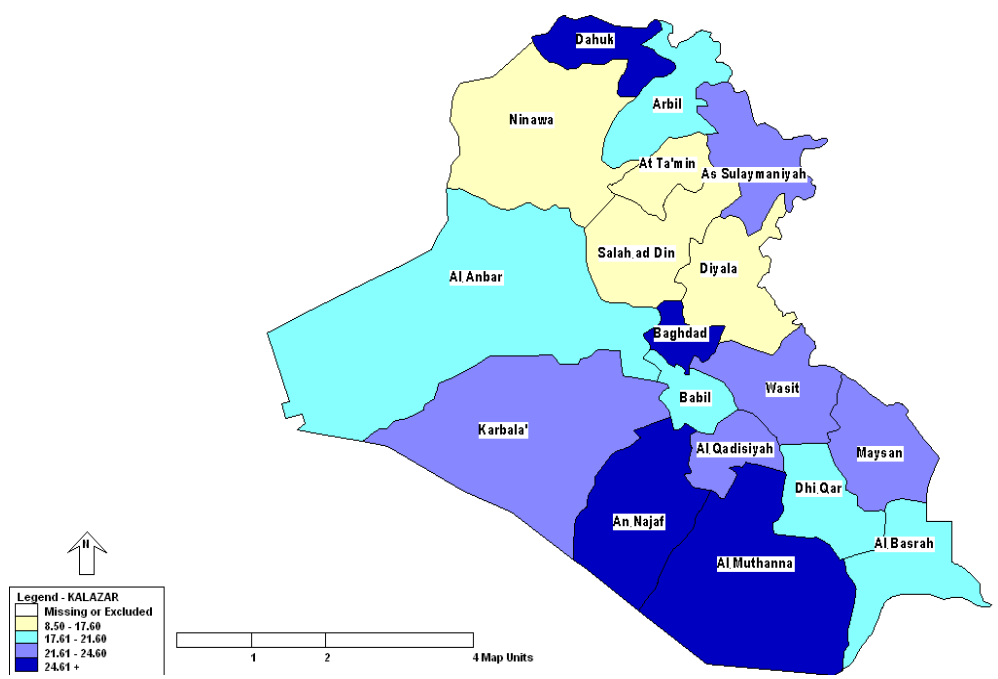

Figure 2. The point prevalence rate of positive serum anti-HEV IgG antibodies in 18 Iraqi governorates in a nationally representative general population sample of 6972 person 